Published in final edited form as:

Inorg Chem. 2016 September 19; 55(18): 9297-9305. doi:10.1021/acs.inorgchem.6b01390.

\title{
Unexpected Changes in the Population of Coordination Isomers for the Lanthanide Ion Complexes of DOTMA-Tetraglycinate
}

\author{
Cemile Kumas $^{\dagger}$, W. Shirangi Fernando ${ }^{\dagger}$, Piyu Zhao ${ }^{\dagger}$, Martín Regueiro-Figueroa§, Garry E. \\ Kiefer $^{\dagger, \ddagger}$, André F. Martins ${ }^{\dagger}$, Carlos Platas-Iglesias ${ }^{\S}$, and A. Dean Sherry ${ }^{*}, \dagger, \|$ \\ tDepartment of Chemistry, University of Texas at Dallas, Dallas, Texas 75080, United States \\ ¥Macrocyclics, Inc., Dallas, Texas 75235, United States \\ §Centro de Investigaciones Científicas Avanzadas (CICA) and Departamento de Química \\ Fundamental, Universidade da Coruña, Campus da Zapateira, Ruá da Fraga 10, 15008 A \\ Coruña, Spain
}

"Advanced Imaging Research Center, University of Texas Southwestern Medical Center, Dallas, Texas 75390, United States

\begin{abstract}
Lanthanide complexes with DOTA-tetraglycinate (DOTA-(gly) 4 ) heavily favor the square antiprismatic (SAP) coordination isomer in aqueous solution, a structural feature that has made them useful as water-based paraCEST agents. In an effort to create amide-based paraCEST agents with rapid water exchange rates, we prepared the analogous tetraglycinate complexes with DOTMA, a ligand known to favor the twisted square antiprismatic (TSAP) coordination structures. Unexpectedly, NMR investigations show that the LnDOTMA-(gly $)_{4}$ complexes, like the LnDOTA-(gly $)_{4}$ complexes, also favor the SAP isomers in solution. This observation led to density functional theory (DFT) calculations in order to identify the energy terms that favor the SAP structures in lanthanide complexes formed with macrocyclic DOTA- and DOTMAtetraamide ligands. The DFT calculations revealed that, regardless the nature of the ligand, the TSAP isomers present more negative hydration energies than the SAP counterparts. The extent to which the TSAP isomer is stabilized varies, however, depending on the ligand structure, resulting in different isomeric populations in solution.
\end{abstract}

\section{Graphical abstract}

\footnotetext{
*Corresponding Author: dean.sherry@utsouthwestern.edu or sherry@utdallas.edu.

Supporting Information

The Supporting Information is available free of charge on the ACS Publications website at DOI: 10.1021/acs.inorgchem.6b01390. 1D, and 2D NMR spectra, CEST spectra, and computational details (PDF)

Author Contributions

This manuscript was written through contributions of all authors. All authors have given approval to the final version of the manuscript.

Notes

The authors declare no competing financial interest.
} 


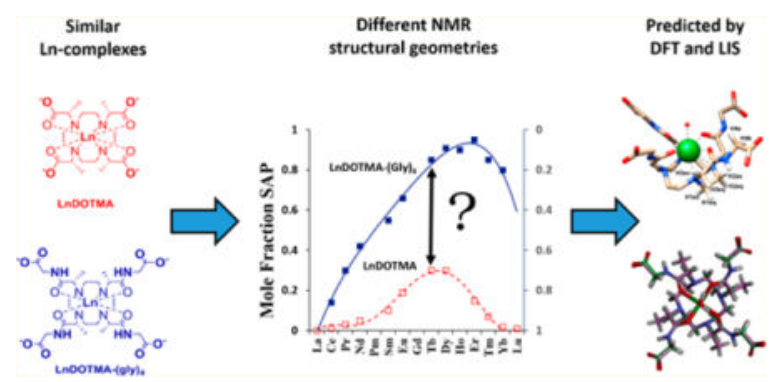

\section{INTRODUCTION}

It is well-established that the population of coordination isomers (square antiprismatic (SAP) vs twisted square antiprismatic(TSAP)) in 9-coordinate lanthanide ion $\left(\mathrm{Ln}^{3+}\right)$ DOTA-type complexes varies as a function of ion size and ligand side-arms (Chart 1). For the LnDOTA complexes, the TSAP isomer predominates for the larger $\mathrm{Ln}^{3+}$ ions while the SAP isomer becomes more favored with a decrease in ionic radii along the series. ${ }^{1}$ For the LnDOTMA complexes, however, the TSAP isomer is favored for nearly all of the complexes due to the steric constraints imposed by the four $a$-methyl groups. ${ }^{2}$ Moreover, all LnDOTA complexes have one inner-sphere-bound water molecule, except for the complexes near the end of the series, as observed in crystals. ${ }^{1,3}$ The rate at which this inner-sphere water molecule exchanges with bulk water can be quite variable and depends upon complex geometry; typically water exchanges more slowly in complexes that favor the SAP coordination isomer and much faster in those favoring the TSAP coordination isomer. The water exchange rate can limit the maximum attainable $r_{1}$ relaxivity in $\mathrm{Gd}^{3+}$ complexes ${ }^{4}$ and also has a big impact on the sensitivity of paraCEST complexes. ${ }^{5} \mathrm{~A}$ requirement for use of such complexes as paraCEST agents is that the chemical exchange rate $\left(k_{\mathrm{ex}}\right)$ must be slower than the frequency difference $(\Delta \omega)$ between the two pools of exchanging protons $\left(k_{\mathrm{ex}}<\Delta \omega\right.$ for exchanging water molecules or ligand protons). For water exchange systems, the SAP isomers display slower water exchange and hence are generally thought to be more favorable for CEST, while the rates of water exchange in TSAP isomers are all too rapid to meet the CEST requirement. ${ }^{6,7}$

In general, LnDOTA-tetraamide complexes that act as paraCEST agents display two types of CEST signals, one from the water molecule exchanging between the inner-sphere of the $\mathrm{Ln}^{3+}$ ion and bulk water and another from the exchangeable amide protons on the ligand itself. $^{8}$ Given that the intensity of any CEST exchange peak in a paramagnetic complex depends upon the exchange characteristics of all exchanging species in the same molecule, ${ }^{9}$ we initiated an investigation of the CEST properties of the LnDOTMA-(gly $)_{4}$ complexes in solution to test whether fast water exchanging complexes, as anticipated for the LnDOTMA(gly) ${ }_{4}$ complexes, would be advantageous for maximizing the CEST signal from the $-\mathrm{NH}$ protons in these complexes. Initially, we assumed that these complexes would mirror the LnDOTMA series and favor the TSAP coordination geometry in solution, thereby yielding paraCEST agents with much faster water exchange properties than the corresponding LnDOTA-(gly) 4 complexes. ${ }^{10-12}$ For water-based paraCEST agents where a bound water resonance is activated to initiate the CEST effect, slow to intermediate water exchange is 
absolutely required. This is the reason EuDOTA-(gly $)_{4}$ has been so popular, because it exhibits one of the slowest water exchange rates. However, for -NH- or -OH-based paraCEST agents where a $-\mathrm{NH}$ or $-\mathrm{OH}$ proton is activated, then having a water molecule in the same complex can impact the CEST intensity of the exchanging - $\mathrm{NH}$ or $-\mathrm{OH}$ proton. In this case, it is preferable to have a complex with a rapidly exchanging water molecule than a complex with a bound water molecule in slow to intermediate exchange. ${ }^{13,14}$ This motivation led to the current study of the LnDOTMA-(gly $)_{4}$ complexes which we anticipated would favor the TSAP isomers in solution and hence display rapid water exchange. Surprisingly, an analysis of the high-resolution NMR spectra of LnDOTMA(gly $)_{4}$ complexes showed that these complexes do not favor the TSAP isomer in solution as observed previously for the symmetric parent LnDOTMA. ${ }^{2}$ This unexpected finding led us to examine the structures of these complexes in detail by high-resolution NMR and to perform density functional theory (DFT) calculations on these complexes in an attempt to explain why the LnDOTMA complexes largely adopt the TSAP structure in solution while the corresponding LnDOTMA-(gly $)_{4}$ complexes largely adopt the SAP structure.

\section{RESULTS AND DISCUSSION}

The ligand DOTMA-(gly $)_{4}$ and the corresponding Ln(III) complexes were prepared using the four-step procedure shown in Scheme 1. The overall yield for the synthetic pathway was $24 \%$ and compounds were used at each step with purities above $90 \%$. The final lanthanide complexes presented purities $>99 \%$ after HPLC purification.

High-resolution ${ }^{1} \mathrm{H}$ NMR spectroscopy was used to estimate the population of SAP and TSAP coordination isomers for ten paramagnetic LnDOTMA-(gly $)_{4}$ complexes in aqueous solution. The ${ }^{1} \mathrm{H}$ NMR spectra of symmetric LnDOTA and LnDOTMA complexes such as this are characterized by two sets of six resonances: one set reflecting the four nonequivalent macrocyclic ethylenediamine protons and two from the methyl acetate side-chain protons of the SAP isomer, and the other six reflecting the corresponding six proton resonances of the TSAP isomer (Figure S5). The paramagnetic lanthanide-induced shifts (LIS) observed for the ethylenediamine proton resonances of the SAP coordination isomer are generally larger than those of the TSAP coordination isomer, so, with this assumption, the intensities of these macrocyclic proton resonances are often used to estimate the population of the two coordination isomers in solution. ${ }^{15,16}$ An example of this is illustrated by the spectra of YbDOTMA and YbDOTMA-(gly $)_{4}$ in Figure 1. Here, the most highly shifted $\mathrm{H}_{4}$ ethylenediamine proton resonance in each complex clearly shows that YbDOTMA existing in solution favors the TSAP isomer (or TSAP' as reported previously ${ }^{2}$ ), while the SAP isomer dominates the spectrum of YbDOTMA-(gly) 4 (Figures S6-S9). It was also quite evident in these spectra that the LIS values of all resonances in YbDOTMA-(gly $)_{4}$ are smaller than the corresponding resonances in YbDOTMA, reflecting the weaker ligand field produced by the four amide oxygen donor atoms in the amide complexes.

To examine whether this trend holds for the entire series of LnDOTMA-(gly $)_{4}$ complexes, high-resolution 1H NMR spectra were recorded for ten different paramagnetic LnDOTMA and LnDOTMA-(gly) ${ }_{4}$ complexes (all except $P m$ and Gd). Although the SAP/TSAP ratios have been reported previously for the LnDOTMA complexes, those spectra were measured 
again here to provide confidence that our procedures for measuring these ratios were consistent with the previous report. As expected, our calculated SAP/TSAP ratios were very close to the ones reported before. ${ }^{2}$ The $\mathrm{H}_{4}$ proton resonances of all ten LnDOTMA-(gly $)_{4}$ complexes are illustrated in Figure 2, and the chemical shifts of the $\mathrm{H}_{4}$ proton resonances in the SAP and TSAP complexes of LnDOTA, LnDOTMA, LnDOTA-(gly) 4 , and LnDOTMA(gly) 4 complexes are reported in Table 1. These comparisons show that the proton chemical shifts in the LnDOTMA complexes are larger than those in the equivalent LnDOTA complexes, consistent with DOTMA providing the strongest ligand field compared to DOTA. A similar trend is seen for the LnDOTMA- $(\mathrm{gly})_{4}$ complexes when compared to the equivalent LnDOTA-(gly $)_{4}$ complexes. The assignments of these resonances to SAP and TSAP were made by the usual assumption that the most highly shifted resonance (either upfield or downfield) reflects the SAP coordination isomer. Given this assumption, one can conclude that CeDOTMA-(gly) $)_{4}$ exists largely as the TSAP isomer in solution ( $\left.\sim 5 \% \mathrm{SAP}\right)$ while the SAP isomer is slightly favored in the SmDOTMA-(gly) $)_{4}$ complex (55\%) and becomes even more dominant as the ion size decreases, reaching a maximum of about $95 \%$ at ErDOTMA-(gly $)_{4}$ before slightly decreasing again near the end of the series. Plots of mole fraction of SAP and TSAP populations for the four series of LnDOTA, LnDOTMA, LnDOTA-(gly) 4 , and LnDOTMA-(gly) 4 complexes are compared in Figure 3.

The gradual switch in population of coordination isomers in the LnDOTA series from largely TSAP at the beginning of the series to largely SAP near the end has been largely ascribed to a gradual decrease in $\operatorname{Ln}(\mathrm{III})$ ionic radii. ${ }^{15,16}$ However, if this were the only factor, it is rather striking to observe an abrupt change in structure from largely TSAP to largely SAP between Nd(III) and Sm(III) in the LnDOTA-(gly) 4 series (Figure 3). A somewhat similar trend was reported for other DOTA derivatives with an extra methylene group included in the macrocyclic ring ${ }^{19,20}$ or where addition of primary and secondary monoamides in the side arms ${ }^{21-23}$ rigidifies the tetraaza macrocycle and forces it to adopt a single isomer structure. The hydrophobicity of the substituents is also known to influence the isomer population in some cases. ${ }^{24}$ In comparison, introduction of carboxylate groups or increasing the polarity of the side arms was shown to stabilize the SAP structure. This indicates there are other factors in addition to ion size that contribute to this structural switch.

The curves of mole fraction of SAP population along the Ln series are surprisingly similar for the LnDOTA and LnDOTMA-(gly $)_{4}$ complexes. To better understand the thermodynamic basis of these observations, DFT calculations were performed on the LnDOTMA, LnDOTMA-(gly $)_{4}$, and LnDOTA-(gly $)_{4}$ series of complexes to determine whether these isomer population trends can be predicted and, if so, whether theory can provide further insights into the factors that favor one coordination isomer over another. The relative free energies of the SAP and TSAP isomers obtained by DFT calculations along the lanthanide series for the three sets of complexes are shown in Figure 4. These data show that DFT is able to capture the main features revealed by the experimental data. For the LnDOTMA complexes, DFT predicts that the TSAP isomer is favored for all $\mathrm{Ln}^{3+}$ complexes but also predicts there may be a slight shift toward the SAP isomer near the center of the Ln series, exactly as seen in the experimental data (Figure 3). The trends predicted by DFT for the LnDOTMA-(gly) ${ }_{4}$ complexes also reasonably mirror the 
experimental results. First, as one can see by the $\Delta G^{\circ}$ differences along the series in Figure 4, the LnDOTMA-(gly) ${ }_{4}$ complexes favor the SAP structures more than the LnDOTMA complexes and there is a larger difference in energy favoring the SAP structures along the series as $\mathrm{Ln}(\mathrm{III})$ ion size decreases, reaching maximum stabilization of the SAP structure near Er. DFT also predicts a more abrupt stabilization of the SAP isomer in the LnDOTA(gly $)_{4}$ complexes near the center of the lanthanide series, although the switch from TSAP to SAP is not as abrupt as that seen experimentally (Figure 3). The main discrepancy between the experimental and calculated data is the slight over-stabilization of the TSAP isomers as estimated by DFT. It is also interesting that DFT calculations predict a slight stabilization of the TSAP isomers at the beginning of the series that is not observed experimentally.

Although we do not have a definitive explanation for this effect, it could be related to the presence of ten-coordinate species in solution, as observed for LaDOTAM in the solid state. $^{25}$

A plot of the Ln-donor distances for geometry optimized LnDOTMA complexes (Figure 5) provides some additional insights into the relative stabilities of the SAP and TSAP isomers across the lanthanide series. All $\mathrm{Ln}-\mathrm{X}$ bond distances decrease along the series as would be expected due to lanthanide contraction. ${ }^{26,27}$ The bond distances of the coordination metal environment of the SAP and TSAP isomers are virtually identical at the beginning of the series but the $\mathrm{Ln}-\mathrm{O}_{\text {water }}$ and $\mathrm{Ln}-\mathrm{O}_{\text {amide }}$ distances gradually diverge across the series as the ionic radius of the $\mathrm{Ln}^{3+}$ ion decreases. As a result, these distances become significantly shorter for the SAP isomer. Thus, a stronger interaction of the lanthanide ion with the oxygen donor atoms of the ligand and the coordinated water molecule explains the increasing stability of the SAP isomer on proceeding to the right across the series. This is in line with previous computational studies, which showed that the increasing stability of the SAP isomer of DOTA-like complexes across the lanthanide series was related to a more favorable binding energy of the ligand to the metal ion. ${ }^{28,29}$

For the LnDOTA series of complexes, the water molecule is expelled from the metal ion coordination sphere for the smallest $\mathrm{Ln}^{3+}$ ions, resulting in eight-coordinated complex species (previously denoted as TSAP'). ${ }^{1}$ Both the $\mathrm{Ln}-\mathrm{O}_{\text {amide }}$ and $\mathrm{Ln}-\mathrm{N}$ distances experience a noticeable shortening upon depletion of the coordinated water molecule, so that these distances are considerably shorter in the TSAP' isomer than in the SAP isomer (Figure 5). In the LnDOTA series, evidence for the TSAP' structure is first observed at TmDOTA, and variable-pressure NMR measurements demonstrated that for the smallest $\mathrm{Ln}^{3+}$ ions the TSAP' isomer was eight-coordinated. ${ }^{30}$ In the LnDOTMA series, evidence for this structure is found earlier, near DyDOTMA (Figure 3), while in the LnDOTMA- $(\mathrm{gly})_{4}$ series, a similar structural change occurs near HoDOTMA-(gly $)_{4}$, both likely reflecting formation of TSAP'like structures that lack an inner-sphere water molecule (Figures S11 and S12). This apparently does not happen for the LnDOTA-(gly $)_{4}$ series as evidenced by two different observations. First, the high-resolution NMR data for the LnDOTA-(gly $)_{4}$ complexes are consistent with the presence of SAP structures along the entire series by the LIS of the $\mathrm{H}_{4}$ resonances (Figure 3 ) and also by the detection of a resonance characteristic of an innersphere water molecule in the YbDOTA-(gly $)_{4}$ complex (Table 2). The fact that this water resonance can be detected by high-resolution NMR indicates that water exchange is relatively slow in this complex. However, the absence of a bound water resonance in the 
spectrum of YbDOTMA-(gly $)_{4}$ does not necessarily mean that a water molecule is not present because water exchange could be too fast to detect by ${ }^{1} \mathrm{H}$ NMR in this complex.

The greater stability of the SAP isomer in LnDOTMA- $(\mathrm{gly})_{4}$ complexes compared to the LnDOTMA analogues was further investigated by calculating the ligand binding energies. The binding energies of the ligand to the metal ion for the LnDOTMA-(gly $)_{4}$ and LnDOTMA complexes were found to be very similar (for details refer to the Supporting Information). Thus, we hypothesized that solvation effects could be responsible for the different isomeric compositions of LnDOTMA-(gly $)_{4}$ and LnDOTMA complexes. Previous computational $^{30}$ and experimental ${ }^{31}$ investigations indicated that solvent had an additional role stabilizing the coordination isomers (s). The dipole moments calculated for the two isomers of LnDOTMA also agree with this conclusion (23.2-24.2 D for the SAP isomers and 29.0-29.2 for the TSAP isomers). A comparison of the hydration free energies calculated for the SAP and TSAP isomers (Figure 6) confirms that the TSAP isomers present more negative free energies of hydration, so that the term $\Delta G_{\text {hyd,TSAP }}^{\circ} \Delta G_{\text {hyd,SAP }}^{\circ}$ is negative for both LnDOTMA-(gly $)_{4}$ and LnDOTMA. In addition, the calculations indicate that in the LnDOTMA complexes the TSAP isomer is more stabilized by solvation than for LnDOTMA- $(\mathrm{gly})_{4}$, with differences in the $\Delta G_{\text {hyd,TSAP }}^{\circ}-\Delta G_{\text {hyd,SAP }}^{\circ}$ term of $0.7-$ $1.4 \mathrm{kcal} \mathrm{mol}^{-1}$. From the populations of the TSAP and SAP isomers shown in Figure 3, the extra stabilization of the TSAP isomer of LnDOTMA complexes with respect to LnDOTMA- $(\text { gly })_{4}$ analogues can be estimated to be in the range $1.7-1.9 \mathrm{kcal} \mathrm{mol}^{-1}(\mathrm{Ln}=$ $\mathrm{Ce}-\mathrm{Dy})$. The $\Delta G_{\text {hyd,TSAP }}^{\circ} \Delta G_{\text {hyd,SAP }}^{\circ}$ terms calculated for the $\mathrm{Gd}^{3+}$ complexes of GdDOTA and GdDOTMA-(gly $)_{4}\left(-5.7\right.$ and $\left.-5.5 \mathrm{kcal} \mathrm{mol}^{-1}\right)$ are virtually identical, in agreement with the very similar populations of the two isomers for these complexes (Figure 3). The $\Delta G_{\text {hyd,TSAP }}^{\circ}-\Delta G_{\text {hyd,SAP }}^{\circ}$ term takes values of $-6.3 \mathrm{kcal} \mathrm{mol}^{-1}$ for GdDOTMA and $-4.0 \mathrm{kcal} \mathrm{mol}^{-1}$ for GdDOTA-(gly $)_{4}$, as would be expected due to the higher abundance of the TSAP and SAP isomers, respectively. Thus, we conclude that solvent stabilization differs among the TSAP isomers depending upon the nature of the ligand, and this results in different isomer populations.

In conclusion, high-resolution NMR spectra of the paramagnetic LnDOTMA-(gly $)_{4}$ complexes reveal that these complexes exist predominantly as TSAP isomers at the beginning of the $\mathrm{Ln}$ series, but then begin to favor the SAP isomer as the $\mathrm{Ln}$ ion size decreases along the series. This behavior is quite different from that seen for the LnDOTMA series of complexes and more like the trend seen along the LnDOTA series. The data show that conversion from a tetracarboxylate ligand, such as DOTA or DOTMA to a tetraamide ligand such as DOTA-(gly $)_{4}$ or DOTMA-(gly $)_{4}$ results in Ln complexes that heavily favor the SAP geometry. The reasons for this behavior were partially revealed by DFT calculations, which show that the TSAP isomers present more negative hydration energies than the SAP isomers. However, the extent to which the TSAP isomer is stabilized by the solvent with respect to the SAP isomer changes depending of the nature of the ligand and this results in different isomeric populations in solution. 


\section{EXPERIMENTAL AND COMPUTATIONAL DETAILS}

\subsection{General Remarks}

Most of the reagents were purchased from VWR and used as received. (-)-Ethyl-L-lactate (CAS 687-47-8), HBTU, glycine ethyl ester hydrochloride, lithium hydroxide monohydrate, and Ln(III) trifluoromethanesulfonate salts were purchased from Sigma-Aldrich. The anhydrous solvents were purchased from Acros and VWR and used in the reactions without further purification. The $\mathrm{CH}_{2} \mathrm{Cl}_{2}$ was distilled over activated molecular sieves before reaction. The solvents used in HPLC and complexation were HPLC grade and used as such, except for water (18.2 $\mathrm{M} \Omega \mathrm{cm}^{-1}$ Milipore water).

\subsection{Synthesis}

3.2.1. $\mathrm{H}_{4}$ DOTMA-The reference procedure was slightly modified to prepare DOTMA ligand. $^{2}$ (-)-Ethyl-L-lactate $(5.7 \mathrm{~mL}, 50 \mathrm{mmol})$ was reacted with triflic anhydride $(9 \mathrm{~mL}, 55$ $\mathrm{mmol})$ in the presence of excess pyridine $(20 \mathrm{~mL})$ and dry dichloromethane $(20 \mathrm{~mL})$ at $0{ }^{\circ} \mathrm{C}$ for $3 \mathrm{~h} .{ }^{32}$ Triflate salt was used without further purification ( $95 \%$ yield). Under an argon atmosphere, triflate of ethyl-L-lactate solution was slowly added to cyclen $(1.7 \mathrm{~g}, 10 \mathrm{mmol})$ solution in anhydrous $\mathrm{CHCl}_{3}(50 \mathrm{~mL})$ and $\mathrm{K}_{2} \mathrm{CO}_{3}(12.7 \mathrm{~g}$, $90 \mathrm{mmol})$. The solution was then heated at $45^{\circ} \mathrm{C}$ for $72 \mathrm{~h}$ and after extraction the crude product was used without further purification. Yield: $5.4 \mathrm{~g}, 85 \%$. DOTMA-4-OEt ${ }^{1} \mathrm{H}$ NMR (400 MHz, acetonitrile- $\left.d_{3}\right): \delta$ (ppm) $1.20\left(\mathrm{~d},{ }^{3} J_{\mathrm{H}-\mathrm{H}} 8 \mathrm{~Hz}, \mathrm{CH}_{3}, 12 \mathrm{H}\right), 1.27\left(\mathrm{t},{ }^{3} J_{\mathrm{H}-\mathrm{H}} 8 \mathrm{~Hz}\right.$, ethyl- $\left.\mathrm{CH}_{3}, 12 \mathrm{H}\right), 2.17$ (dt, ${ }^{3} J_{\mathrm{H}-\mathrm{H}} 4 \mathrm{~Hz},{ }^{3} J_{\mathrm{H}-\mathrm{H}} 12 \mathrm{~Hz}$, cyclen $\left.\mathrm{CH}_{2}, 4 \mathrm{H}\right), 2.37\left(\mathrm{dt},{ }^{3} J_{\mathrm{H}-\mathrm{H}} 4 \mathrm{~Hz},{ }^{3} J_{\mathrm{H}-\mathrm{H}} 12 \mathrm{~Hz}\right.$, cyclen $\left.\mathrm{CH}_{2}, 4 \mathrm{H}\right), 2.66\left(\mathrm{dt},{ }^{3} J_{\mathrm{H}-\mathrm{H}} 4 \mathrm{~Hz},{ }^{3} J_{\mathrm{H}-\mathrm{H}} 12 \mathrm{~Hz}\right.$, cyclen $\left.\mathrm{CH}_{2}, 4 \mathrm{H}\right), 2.93\left(\mathrm{dt},{ }^{3} J_{\mathrm{H}-\mathrm{H}} 4 \mathrm{~Hz},{ }^{3} J_{\mathrm{H}-\mathrm{H}}\right.$ $12 \mathrm{~Hz}$, cyclen $\left.\mathrm{CH}_{2}, 4 \mathrm{H}\right), 3.74$ (q, ${ }^{3} \mathrm{~J}_{\mathrm{H}-\mathrm{H}} 4 \mathrm{~Hz}$, chiral CH, $\left.4 \mathrm{H}\right), 4.15\left(\mathrm{~m}, \mathrm{NH}-\mathrm{CH}_{2}, 8 \mathrm{H}\right) .{ }^{13} \mathrm{C}$ NMR (400 MHz, acetonitrile- $\left.d_{3}\right): \delta(\mathrm{ppm}) 6.6,13.5,29.8,44.2,46.9,56,61,117.7,175.7$.

The ester cleavage of DOTMA ligand is achieved by $\mathrm{NaOH}(2.6 \mathrm{~g}, 65 \mathrm{mmol})$ addition in the THF-water biphasic solution $(50 \mathrm{~mL} / 60 \mathrm{~mL})$ and then heated at $50{ }^{\circ} \mathrm{C}$ for $18 \mathrm{~h}$. The sodium salt of DOTMA was crystallized from hot water. $\mathrm{Na}_{4}$ DOTMA was acidified with $5 \mathrm{M} \mathrm{HCl}$ to $\mathrm{pH} 2-3$ and lyophilized to yield $\mathrm{H}_{4}$ DOTMA. Yield: $3.8 \mathrm{~g}, 90 \%$. ${ }^{1} \mathrm{H}$ NMR $(400 \mathrm{MHz}$, $\mathrm{D}_{2} \mathrm{O}$ ): $\delta(\mathrm{ppm}) 1.29\left(\mathrm{~d},{ }^{3} \mathrm{~J}_{\mathrm{H}-\mathrm{H}} 8 \mathrm{~Hz}, \mathrm{CH}_{3}, 12 \mathrm{H}\right), 3.11$ (b, cyclen $\left.\mathrm{CH}_{2}, 16 \mathrm{H}\right), 3.78$ (b, chiral $\mathrm{CH}, 4 \mathrm{H})$.

3.2.2. Ethyl Ester of DOTMA-(gly $)_{4}$-The $\mathrm{H}_{4}$ DOTMA ligand ( $1.06 \mathrm{~g}, 2 \mathrm{mmol}$ ) was suspended in $25 \mathrm{~mL}$ of DMF, and 18 equiv DIPEA $(6.3 \mathrm{~mL}, 36 \mathrm{mmol})$ was added to the stirring mixture. The solution was stirred for 5-10 min after adding 4.5 equiv HBTU ( $3.4 \mathrm{~g}$, $9 \mathrm{mmol})$. The 4.5 equiv of glycine ethyl ester hydrochloride $(1.25 \mathrm{~g}, 9 \mathrm{mmol})$ was added to the mixture and stirred at room temperature for $12 \mathrm{~h}$. The mixture was dried under reduced pressure to dryness at $60{ }^{\circ} \mathrm{C}$ and the oil residue was dissolved in dichloromethane to be washed three times with $1 \mathrm{~N} \mathrm{NaOH}$. The organic layer was dried over sodium sulfate, filtered, and dried. The ethyl ester of DOTMA- $(\mathrm{gly})_{4}$ was purified by prep-HPLC to yield a white powder. Preparative HPLC, $R_{f}=14.2 \mathrm{~min}$, (90\%) Kinetex $5 \mu \mathrm{m} \mathrm{C18}$ reversed phase column, Phenomenex $250 \times 21.2 \mathrm{~mm}, 100 \AA$, water $(0.1 \%$ TFA)/acetonitrile $(0.1 \%$ TFA), 95/5\% to 50/50\% in $16 \mathrm{~min}$, flow rate $30 \mathrm{~mL} / \mathrm{min}$, gradient). Yield: $0.56 \mathrm{~g}, 35 \% .{ }^{1} \mathrm{H}$ NMR (400 MHz, $\mathrm{D}_{2} \mathrm{O}$ ): $\delta(\mathrm{ppm}) 0.98\left(\mathrm{t},{ }^{3} J_{\mathrm{H}-\mathrm{H}} 8 \mathrm{~Hz}\right.$, ethyl- $\left.\mathrm{CH}_{3}, 12 \mathrm{H}\right), 1.00\left(\mathrm{~d},{ }^{3} \mathrm{~J}_{\mathrm{H}-\mathrm{H}} 8 \mathrm{~Hz}, \mathrm{CH}_{3}\right.$, 
$12 \mathrm{H}$ ), 2.01 (cyclen $\mathrm{CH}_{2}, 4 \mathrm{H}$ ), 2.22 (cyclen $\mathrm{CH}_{2}, 4 \mathrm{H}$ ), 2.54 (cyclen $\mathrm{CH}_{2}, 4 \mathrm{H}$ ), 2.74 (cyclen $\left.\mathrm{CH}_{2}, 4 \mathrm{H}\right), 3.35$ (m, chiral $\left.\mathrm{CH}, 4 \mathrm{H}\right), 3.46\left(\mathrm{~m}, \mathrm{NH}-\mathrm{CH}_{2}, 8 \mathrm{H}\right), 3.68\left(\mathrm{~b}, \mathrm{O}-\mathrm{CH}_{2}, 8 \mathrm{H}\right) .{ }^{13} \mathrm{C}$ NMR (400 MHz, acetonitrile- $d_{3}$ ): $\delta$ (ppm) 7.5, 14.0, 44.5, 47.0, 56.2, 61.4, 175.9. ESI-MS (positive detection mode): $\mathrm{m} / \mathrm{z}(\%) 801.27[\mathrm{M}+\mathrm{H}]^{+}$.

3.2.3. DOTMA-(gly $)_{4}$ and Complexation-The cleavage of the ester groups was achieved by stirring overnight a solution of the ester $(100 \mathrm{mg}, 0.12 \mathrm{mmol})$ with $6 \mathrm{~N} \mathrm{LiOH}$ (34 $\mathrm{mg}, 0.8 \mathrm{mmol}$ ) and $2 \mathrm{~mL}$ of water at room temperature. The reaction was monitored by HPLC until hydrolysis was complete and then the solution was lyophilized to give a white powder. Yield: $81 \mathrm{mg}, 95 \%$. DOTMA-(gly $)_{4}{ }^{1} \mathrm{H}$ NMR (400 MHz, $\left.\mathrm{D}_{2} \mathrm{O}\right): \delta$ (ppm 1.10 (d, $\left.\mathrm{CH}_{3}, 12 \mathrm{H}\right), 2.24$ (b, cyclen $\left.\mathrm{CH}_{2}, 8 \mathrm{H}\right), 2.75$ (b, cyclen $\left.\mathrm{CH}_{2}, 8 \mathrm{H}\right), 3.55\left(\mathrm{~m}, \mathrm{NH}-\mathrm{CH}_{2}, 8 \mathrm{H}\right)$ 3.78 (b, chiral CH, 4H). ${ }^{13} \mathrm{C}$ NMR (400 MHz, $\mathrm{D}_{2} \mathrm{O}$ ): $\delta$ (ppm) 16.5, 38.7, 39.6, 43.4, 46.2, 171.1, 171.3, 173.3. ESI-MS (positive detection mode): $m / z(\%) 689.02[\mathrm{M}+\mathrm{H}]^{+}$.

Complexes were formed by addition of equimolar amounts of $\operatorname{Ln}(\mathrm{III})$ trifluoromethanesulfonate salts to a solution of DOTMA- $(\mathrm{gly})_{4}$ in $1: 1 \mathrm{ACN} / \mathrm{H}_{2} \mathrm{O}$ mixture at $45^{\circ} \mathrm{C}$ with the $\mathrm{pH}$ maintained near 5.5, about 1-3 days. The progress of ester cleavage and lanthanide complexations was monitored by reverse-phase analytical HPLC using a Phenomenex Luna C18 column, $5 \mu \mathrm{m}(150 \times 3.0 \mathrm{~mm})$. The absorbance was monitored at $215 \mathrm{~nm}$, and the solvent system elution started with $98 \%$ water $(0.1 \%$ TFA $) / 2 \%$ acetonitrile ( $0.1 \%$ TFA) followed by a linear gradient to $40 \%$ water $(0.1 \%$ TFA $) / 60 \%$ acetonitrile $(0.1 \%$ TFA) over $30 \mathrm{~min}$ (Supporting Information), at a flow rate of $1 \mathrm{~mL} / \mathrm{min}$ (see Supporting Information for further details). After completion, the excess metal was filtered off by adjusting the $\mathrm{pH}$ of the complex to $\sim 8.5$. The solvent was removed under reduced pressure. The dry compound was then redissolved in a minimum amount of water. The solution was added dropwise to a flask containing THF, and the formed precipitate (the pure product) was collected by centrifugation.

\subsection{NMR}

${ }^{1} \mathrm{H}$ NMR spectra and CEST spectra were recorded on a $400 \mathrm{MHz}$ Bruker Avance III spectrometer. High-resolution ${ }^{1} \mathrm{H}$ NMR samples were prepared either in $\mathrm{D}_{2} \mathrm{O}$ or $\mathrm{H}_{2} \mathrm{O}$. Samples for CEST studies were prepared by dissolving the appropriate amount of agent in water and the $\mathrm{pH}$ was adjusted to neutral.

\subsection{Computational Details}

All calculations were performed employing DFT within the hybrid meta-GGA approximation with the TPSSh exchange-correlation functional, ${ }^{33}$ and the Gaussian 09 package (Revision D.01). ${ }^{34}$ Full geometry optimizations of the $\left[\operatorname{Ln}\left(\text { DOTMA) }-\left(\mathrm{H}_{2} \mathrm{O}\right)\right]^{-}\right.$, $\left[\mathrm{Ln}\left(\text { DOTMA- }(\mathrm{gly})_{4}\left(\mathrm{H}_{2} \mathrm{O}\right)\right]^{-},\left[\mathrm{Ln}\left(\text { DOTA- }(\mathrm{gly})_{4}\left(\mathrm{H}_{2} \mathrm{O}\right)\right]^{-}\right.\right.$, and $\left[\mathrm{Gd}(\mathrm{DOTA})\left(\mathrm{H}_{2} \mathrm{O}\right)\right]^{-}$ complexes were performed in aqueous solution by using the large-core relativistic effective core potential (LCRECP) of Dolg et al. and the related (7s6p5d)/[5s4p3d]-GTO valence basis set for the lanthanides, ${ }^{35}$ and the standard 6-31G(d,p) basis set for $\mathrm{C}, \mathrm{H}, \mathrm{N}$ and $\mathrm{O}$ atoms. Input geometries for geometry optimization purposes were generated from the structures of $\left[\operatorname{Ln}(\text { DOTA })\left(\mathrm{H}_{2} \mathrm{O}\right)\right]^{-}$and $\left[\operatorname{Ln}(\text { DOTAM })\left(\mathrm{H}_{2} \mathrm{O}\right)\right]^{3+}$ obtained in a previous computational study. ${ }^{36}$ This LCRECP includes $46+4 \mathrm{f}^{\mathrm{n}}$ electrons in the core for the 
lanthanide, leaving the outermost 11 electrons ( $5 \mathrm{~s}, 5 \mathrm{p}, 5 \mathrm{~d}$, and $6 \mathrm{~s}$ ) to be treated explicitly. Given that $4 \mathrm{f}$ electrons were included in the core, our calculations were conducted on a pseudosinglet state configuration. No symmetry constraints were imposed during the optimizations. The default values for the integration grid ( 75 radial shells and 302 angular points) and the SCF energy convergence criteria $\left(10^{-8}\right)$ were used for the calculations of $\left[\mathrm{Ln}(\mathrm{DOTMA})\left(\mathrm{H}_{2} \mathrm{O}\right)\right]^{-}$and $\left[\mathrm{Ln}\left(\mathrm{DOTMA}-(\mathrm{gly})_{4}\left(\mathrm{H}_{2} \mathrm{O}\right)\right]^{-}\right.$, while for [ $\mathrm{Ln}(\mathrm{DOTA}-$ $\left.(\mathrm{gly})_{4}\left(\mathrm{H}_{2} \mathrm{O}\right)\right]^{-}$and $\left[\mathrm{Gd}(\mathrm{DOTA})\left(\mathrm{H}_{2} \mathrm{O}\right)\right]^{-}$complexes an ultrafine grid (99 radial shells and 590 angular points) was used to facilitate the convergence of the geometry optimizations. The stationary points found on the potential energy surfaces as a result of the geometry optimizations have been tested to represent energy minima rather than saddle points via frequency analysis. The relative free energies of the SAP and TSAP conformations include non-potential-energy contributions (zero point energies and thermal terms) obtained through frequency calculations. Bulk solvent effects (water) were evaluated by using the polarizable continuum model (PCM), in which the solute cavity is built as an envelope of spheres centered on atoms or atomic groups with appropriate radii. In particular, we used the integral equation formalism (IEFPCM) ${ }^{37}$ variant as implemented in Gaussian 09 . The universal force field radii $(\mathrm{UFF})^{38}$ scaled by a factor of 1.1 were used to define the solute cavities of $\left[\operatorname{Ln}(\text { DOTMA })\left(\mathrm{H}_{2} \mathrm{O}\right)\right]^{-}$and $\left[\operatorname{Ln}\left(\text { DOTMA- }(\mathrm{gly})_{4}\left(\mathrm{H}_{2} \mathrm{O}\right)\right]^{-}\right.$, while a scaling factor of 1.2 was employed for $\left[\mathrm{Ln}\left(\mathrm{DOTA}-(\mathrm{gly})_{4}\left(\mathrm{H}_{2} \mathrm{O}\right)\right]^{-}\right.$and $\left[\mathrm{Gd}(\mathrm{DOTA})\left(\mathrm{H}_{2} \mathrm{O}\right)\right]^{-}$complexes.

The binding energies (BE) in these complexes were calculated in the gas phase as the energy of the complex less that of the metal ion plus that of the ligand (with the ligand in the same geometry as found in the complex). Therefore, binding energies were static, as they did not include energy contributions due to changes in ligand geometry. Basis Set Superposition Errors (BSSEs) were calculated using the standard Counterpoise method. ${ }^{39}$ Relative strain energies (SE) were calculated as the relative energies of the ligands in their geometry found within the SAP and TSAP isomers.

\section{Supplementary Material}

Refer to Web version on PubMed Central for supplementary material.

\section{Acknowledgments}

We thank Namini Parawithana for preparing and purifying several lanthanide complexes.

Funding

This work was supported in part by grants from the National Institutes of Health (CA115531, EB015908, and EB004582) and the Robert A. Welch Foundation (AT-584). Author C.P.-I acknowledges Ministerio de Economía y Competitividad (CTQ2013-43243-P and CTQ2015-71211-REDT) for generous financial support and Centro de Supercomputación de Galicia (CESGA) for providing the supercomputer facilities.

\section{References}

1. Benetollo F, Bombieri G, Calabi L, Aime S, Botta M. Structural Variations Across the Lanthanide Series of Macrocyclic DOTA Complexes: Insights into the Design of Contrast Agents for Magnetic Resonance Imaging. Inorg Chem. 2003; 42:148-157. [PubMed: 12513089] 
2. Aime S, Botta M, Garda Z, Kucera BE, Tircso G, Young VG, Woods M. Properties, Solution State Behavior, and Crystal Structures of Chelates of DOTMA. Inorg Chem. 2011; 50:7955-7965. [PubMed: 21819052]

3. Miller KJ, Saherwala AA, Webber BC, Wu Y, Sherry AD, Woods M. The Population of SAP and TSAP Isomers in Cyclen-Based Lanthanide(III) Chelates Is Substantially Affected by Solvent. Inorg Chem. 2010; 49:8662-8664. [PubMed: 20812752]

4. Fernando WS, Martins AF, Zhao P, Wu Y, Kiefer GE, Platas-Iglesias C, Sherry AD. Breaking the Barrier to Slow Water Exchange Rates for Optimal Magnetic Resonance Detection of paraCEST Agents. Inorg Chem. 2016; 55:3007-3014. [PubMed: 26937683]

5. Wu Y, Zhang S, Soesbe TC, Yu J, Vinogradov E, Lenkinski RE, Sherry AD. pH imaging of mouse kidneys in vivo using a frequency-dependent paraCEST agent. Magn Reson Med. 2016; 75:24322441. [PubMed: 26173637]

6. Aime S, Barge A, Bruce JI, Botta M, Howard JAK, Moloney JM, Parker D, de Sousa AS, Woods MJ. Relaxometric, and Structural Studies of the Hydration and Exchange Dynamics of Cationic Lanthanide Complexes of Macrocyclic Tetraamide Ligands. J Am Chem Soc. 1999; 121:57625771.

7. Dunand FA, Aime S, Merbach AE. First ${ }^{17} \mathrm{O}$ NMR Observation of Coordinated Water on Both Isomers of [Eu-(DOTAM $\left.)\left(\mathrm{H}_{2} \mathrm{O}\right)\right]^{3+}$ : A Direct Access to Water Exchange and its Role in the Isomerization. J Am Chem Soc. 2000; 122:1506-1512.

8. Zhang S, Merritt M, Woessner DE, Lenkinski RE, Sherry AD. PARACEST Agents: Modulating MRI Contrast via Water Proton Exchange. Acc Chem Res. 2003; 36:783-790. [PubMed: 14567712]

9. Woessner DE, Zhang S, Merritt ME, Sherry AD. Numerical solution of the Bloch equations provides insights into the optimum design of PARACEST agents for MRI. Magn Reson Med. 2005; 53:790-799. [PubMed: 15799055]

10. Aime S, Barge A, Delli Castelli D, Fedeli F, Mortillaro A, Nielsen FU, Terreno E. Paramagnetic Lanthanide(III) complexes as $\mathrm{pH}$-sensitive chemical exchange saturation transfer (CEST) contrast agents for MRI applications. Magn Reson Med. 2002; 47:639-648. [PubMed: 11948724]

11. Vipond J, Woods M, Zhao P, Tircsó G, Ren J, Bott SG, Ogrin D, Kiefer GE, Kovacs Z, Sherry AD. A Bridge to Coordination Isomer Selection in Lanthanide(III) DOTA-tetraamide Complexes. Inorg Chem. 2007; 46:2584-2595. [PubMed: 17295475]

12. Opina ACL, Ghaghada KB, Zhao P, Kiefer G, Annapragada A, Sherry AD. TmDOTATetraglycinate Encapsulated Liposomes as pH-Sensitive LipoCEST Agents. PLoS One. 2011; 6:e27370. [PubMed: 22140438]

13. Evbuomwan OM, Lee J, Woods M, Sherry AD. The Presence of Fast-Exchanging Proton Species in Aqueous Solutions of paraCEST Agents Can Impact Rate Constants Measured for Slower Exchanging Species When Fitting CEST Spectra to the Bloch Equations. Inorg Chem. 2014; 53:10012-10014. [PubMed: 25210979]

14. Tircso G, Webber BC, Kucera BE, Young VG, Woods M. Analysis of the conformational behavior and stability of the SAP and TSAP isomers of lanthanide(III) NB-DOTA-type chelates. Inorg Chem. 2011; 50:7966-7979. [PubMed: 21819053]

15. Aime S, Botta M, Ermondi G. NMR study of solution structures and dynamics of lanthanide(III) complexes of DOTA. Inorg Chem. 1992; 31:4291-4299.

16. Marques MPM, Geraldes CFGC, Sherry AD, Merbach AE, Powell H, Pubanz D, Aime S, Botta M. NMR conformational study of the lanthanide(III) complexes of DOTA in aqueous solution. $\mathrm{J}$ Alloys Compd. 1995; 225:303-307.

17. Viswanathan S, Kovacs Z, Green KN, Ratnakar SJ, Sherry AD. Alternatives to Gadolinium-based MRI Metal Chelates. Chem Rev. 2010; 110:2960-3018. [PubMed: 20397688]

18. Delli Castelli D, Caligara MC, Botta M, Terreno E, Aime S. Combined High Resolution NMR and $1 \mathrm{H}$ and $17 \mathrm{O}$ Relaxometric Study Sheds Light on the Solution Structure and Dynamics of the Lanthanide(III) Complexes of HPDO3A. Inorg Chem. 2013; 52:7130-7138. [PubMed: 23738541]

19. Jacques V, Gilsoul D, Comblin V, Desreux JF. Rigidified macrocyclic lanthanide chelates for magnetic resonance imaging. J Alloys Compd. 1997; 249:173-177.

20. Ranganathan RS, Raju N, Fan H, Zhang X, Tweedle MF, Desreux JF, Jacques V. Polymethylated DOTA Ligands. 2. Synthesis of Rigidified Lanthanide Chelates and Studies on the Effect of Alkyl 
Substitution on Conformational Mobility and Relaxivity. Inorg Chem. 2002; 41:6856-6866. [PubMed: 12470084]

21. Aime S, Botta M, Garino E, Geninatti Crich S, Giovenzana G, Pagliarin R, Palmisano G, Sisti M. Non-covalent Conjugates between Cationic Polyamino Acids and GdIII Chelates: A Route for Seeking Accumulation of MRI-Contrast Agents at Tumor Targeting Sites. Chem - Eur J. 2000; 6:2609-2617. [PubMed: 10961406]

22. Kubíček V, Rudovský J, Kotek J, Hermann P, Vander Elst L, Muller RN, Kolar ZI, Wolterbeek HT, Peters JA, Lukeš I. A Bisphosphonate Monoamide Analogue of DOTA: A Potential Agent for Bone Targeting. J Am Chem Soc. 2005; 127:16477-16485. [PubMed: 16305234]

23. Ferreira MF, Martins AF, Martins JA, Ferreira PM, Tóth É, Geraldes CFGC. Gd(DO3A-N- $a$ aminopropionate): a versatile and easily available synthon with optimized water exchange for the synthesis of high relaxivity, targeted MRI contrast agents. Chem Commun. 2009:6475.

24. Mani T, Tircsó G, Togao O, Zhao P, Soesbe TC, Takahashi M, Sherry AD. Modulation of water exchange in Eu(III) DOTA-tetraamide complexes: considerations for in vivo imaging of PARACEST agents. Contrast Media Mol Imaging. 2009; 4:183-191. [PubMed: 19672854]

25. Amin S, Morrow JR, Lake CH, Churchill MR. Lanthanide(III) Tetraamide Macrocyclic Complexes as Synthetic Ribonucleases: Structure and Catalytic Properties of [La(tcmc) (CF3SO3) (EtOH)] (CF3SO3)2. Angew Chem, Int Ed Engl. 1994; 33:773-775.

26. Seitz M, Oliver AG, Raymond KN. The Lanthanide Contraction Revisited. J Am Chem Soc. 2007; 129:11153-11160. [PubMed: 17705483]

27. Regueiro-Figueroa M, Esteban-Gómez D, de Blas A, Rodríguez-Blas T, Platas-Iglesias C. Understanding Stability Trends along the Lanthanide Series. Chem - Eur J. 2014; 20:3974-3981. [PubMed: 24577810]

28. Purgel M, Baranyai Z, de Blas A, Rodríguez-Blas T, Bányai I, Platas-Iglesias C, Tóth I. An NMR and DFT Investigation on the Conformational Properties of Lanthanide(III) 1,4,7,10Tetraazacyclododecane-1,4,7,10-tetraacetate Analogues Containing Methylenephosphonate Pendant Arms. Inorg Chem. 2010; 49:4370-4382. [PubMed: 20369836]

29. Platas-Iglesias C. The Solution Structure and Dynamics of MRI Probes Based on Lanthanide(III) DOTA as Investigated by DFT and NMR Spectroscopy. Eur J Inorg Chem. 2012; 2012:2023-2033.

30. Aime S, Botta M, Fasano M, Marques MPM, Geraldes CFGC, Pubanz D, Merbach AE. Conformational and Coordination Equilibria on DOTA Complexes of Lanthanide Metal Ions in Aqueous Solution Studied by ${ }^{1}$ H-NMR Spectroscopy. Inorg Chem. 1997; 36:2059-2068. [PubMed: 11669824]

31. Cosentino U, Villa A, Pitea D, Moro G, Barone V, Maiocchi A. Conformational Characterization of Lanthanide(III)-DOTA Complexes by ab Initio Investigation in Vacuo and in Aqueous Solution. J Am Chem Soc. 2002; 124:4901-4909. [PubMed: 11971741]

32. Diana GD, Rudewicz P, Pevear DC, Nitz TJ, Aldous SC, Aldous DJ, Robinson DT, Draper T, Dutko FJ, Aldi C, et al. Picornavirus inhibitors: trifluoromethyl substitution provides a global protective effect against hepatic metabolism. J Med Chem. 1995; 38:1355-1371. [PubMed: 7731021]

33. Tao J, Perdew JP, Staroverov VN, Scuseria GE. Climbing the density functional ladder: nonempirical meta-generalized gradient approximation designed for molecules and solids. Phys Rev Lett. 2003; 91:146401. [PubMed: 14611541]

34. Frisch, MJ.; Trucks, GW.; Schlegel, HB.; Scuseria, GE.; Robb, MA.; Cheeseman, JR.; Scalmani, G.; Barone, V.; Mennucci, B.; Petersson, GA.; Nakatsuji, H.; Caricato, M.; Li, X.; Hratchian, HP.; Izmaylov, AF.; Bloino, J.; Zheng, G.; Sonnenberg, JL.; Hada, M.; Ehara, M.; Toyota, K.; Fukuda, R.; Hasegawa, J.; Ishida, M.; Nakajima, T.; Honda, Y.; Kitao, O.; Nakai, H.; Vreven, T.; Montgomery, JA., Jr; Peralta, JE.; Ogliaro, F.; Bearpark, M.; Heyd, JJ.; Brothers, E.; Kudin, KN.; Staroverov, VN.; Kobayashi, R.; Normand, J.; Raghavachari, K.; Rendell, A.; Burant, JC.; Iyengar, SS.; Tomasi, J.; Cossi, M.; Rega, N.; Millam, JM.; Klene, M.; Knox, JE.; Cross, JB.; Bakken, V.; Adamo, C.; Jaramillo, J.; Gomperts, R.; Stratmann, RE.; Yazyev, O.; Austin, AJ.; Cammi, R.; Pomelli, C.; Ochterski, JW.; Martin, RL.; Morokuma, K.; Zakrzewski, VG.; Voth, GA.; Salvador, P.; Dannenberg, JJ.; Dapprich, S.; Daniels, AD.; Farkas, O.; Foresman, JB.; Ortiz, JV.; Cioslowski, J.; Fox, DJ. Gaussian 09, revision D.01. Gaussian, Inc.; Wallingford, CT: 2009. 
35. Dolg M, Stoll H, Savin A, Preuss H. Energy-adjusted pseudopotentials for the rare earth elements. Theor Chim Acta. 1989; 75:173-194.

36. Regueiro-Figueroa M, Platas-Iglesias C. Towards the Prediction of Water Exchange Rates in MRI Contrast Agents: A DFT Study. J Phys Chem A. 2015; 119:6436-6445. [PubMed: 26000832]

37. Tomasi J, Mennucci B, Cammi R. Quantum Mechanical Continuum Solvation Models. Chem Rev. 2005; 105:2999-3094. [PubMed: 16092826]

38. Rappe AK, Casewit CJ, Colwell KS, Goddard WA, Skiff WM. UFF, a full periodic table force field for molecular mechanics and molecular dynamics simulations. J Am Chem Soc. 1992; 114:1002410035.

39. Boys SF, Bernardi F. The calculation of small molecular interactions by the differences of separate total energies. Some procedures with reduced errors. Mol Phys. 1970; 19:553-566. 

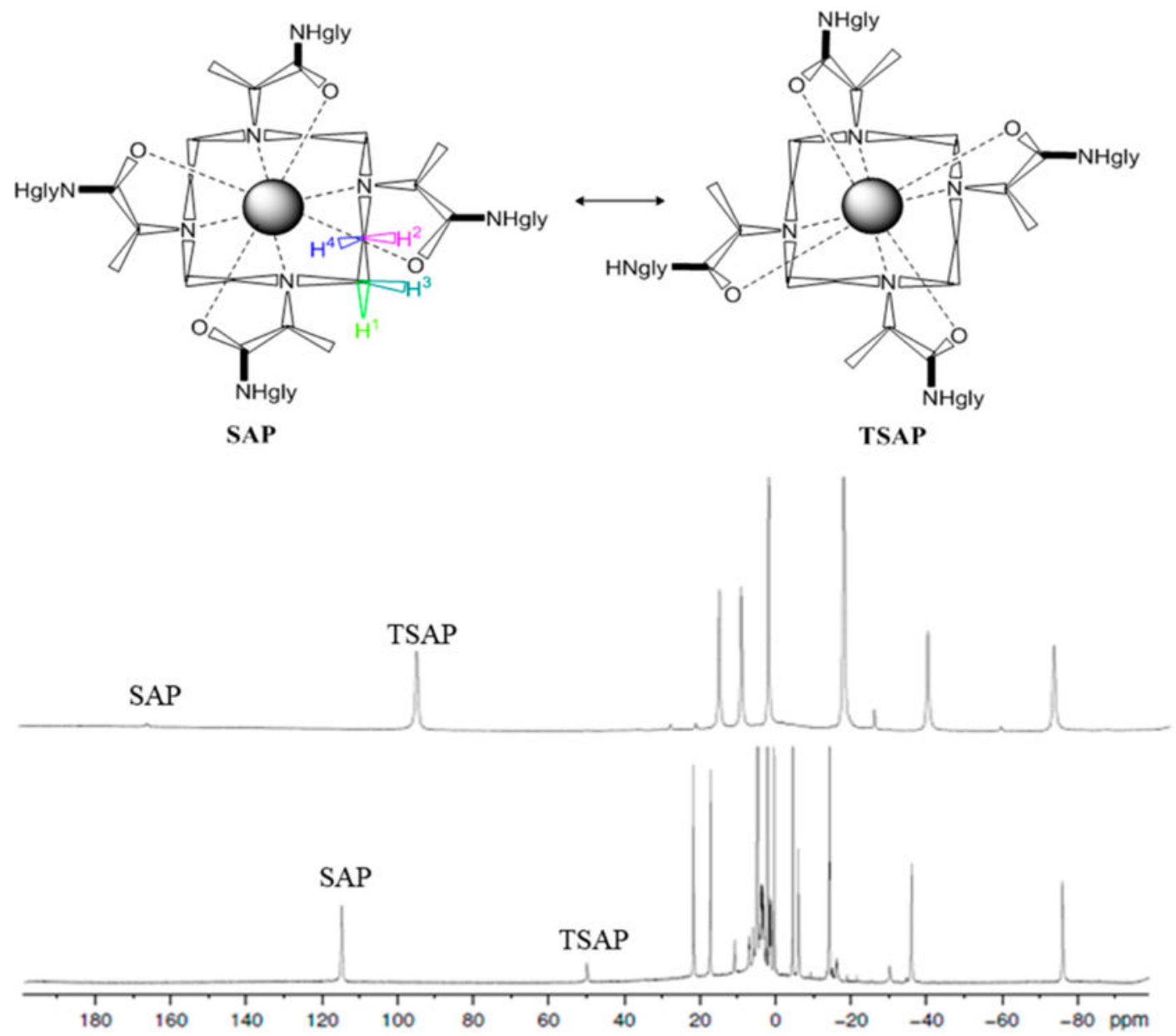

Figure 1.

${ }^{1} \mathrm{H}$ NMR spectra of YbDOTMA (top) and YbDOTMA-(gly) 4 (bottom). All spectra were recorded in $\mathrm{D}_{2} \mathrm{O}$ at $400 \mathrm{MHz}, 298 \mathrm{~K}$. The axial $\mathrm{H}_{4}$ protons of the SAP and TSAP isomers are labeled. 

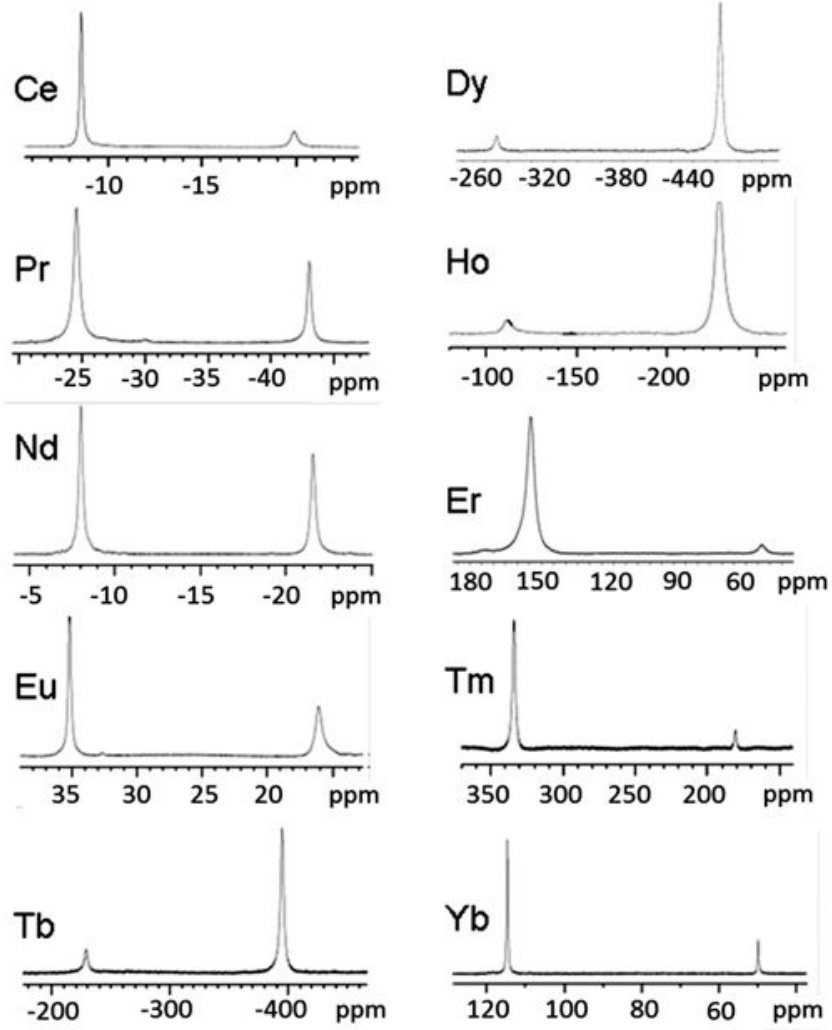

Figure 2.

${ }^{1} \mathrm{H}$ NMR spectra of ten different LnDOTMA- $(\mathrm{gly})_{4}$ complexes recorded in $\mathrm{D}_{2} \mathrm{O}$, pD 7.0 showing only the most upfield or downfield resonances characteristic of the $\mathrm{H}_{4}$ resonances. The most highly shifted resonances were assigned to the SAP isomers. 

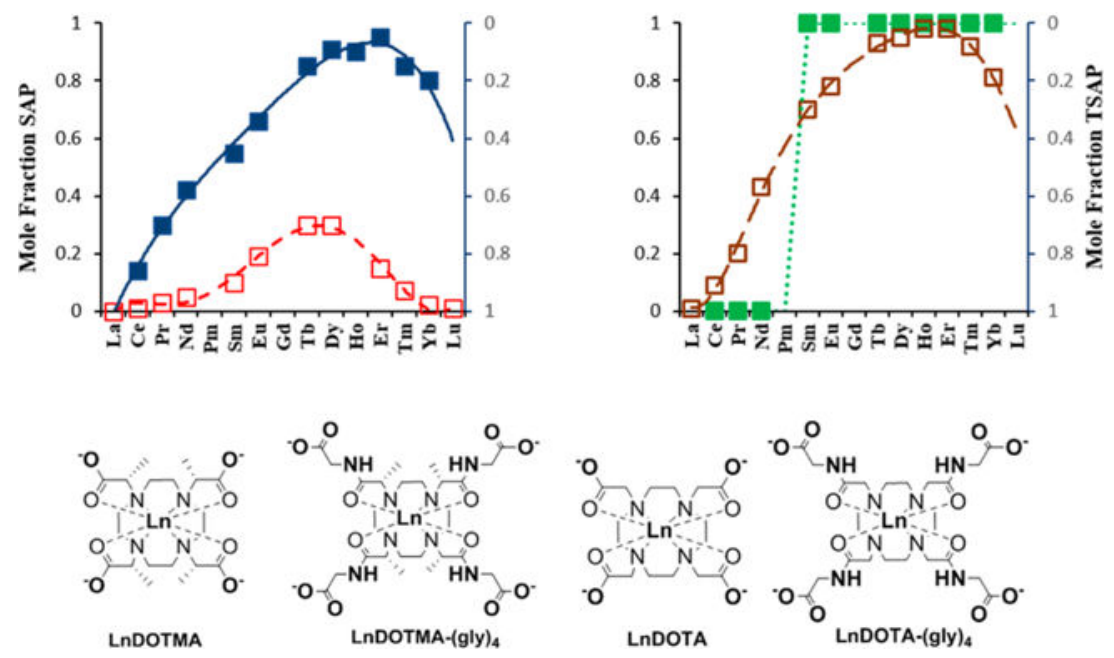

Figure 3.

Mole fractions of SAP (left axis) and TSAP (right axis) coordination isomers for the LnDOTMA (red) and LnDOTMA-(gly) 4 (blue) complexes for ten paramagnetic lanthanides (left graph). Published data for LnDOTA (brown) and LnDOTA-(gly) 4 (green) (right graph) are also shown for comparative purposes. ${ }^{2,11,18}$ 


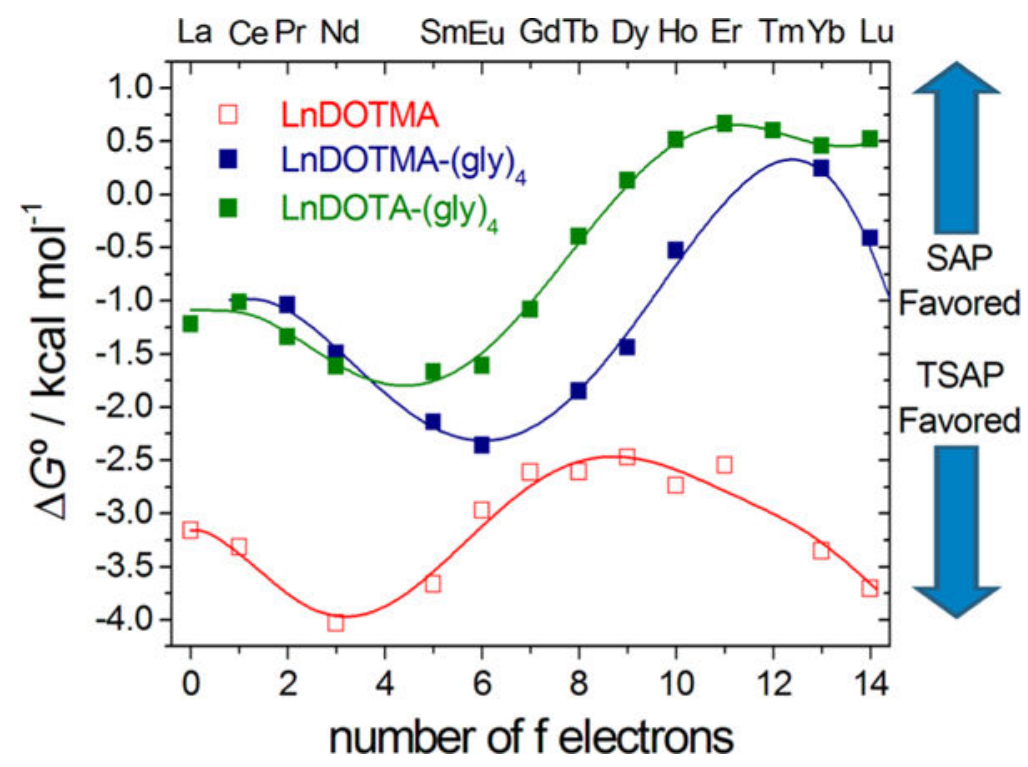

Figure 4.

Difference in free energies between the SAP and TSAP isomers $\left(\Delta G^{\circ}=G^{\circ}\right.$ TSAP $-G_{\text {SAP }}^{\circ}$ of LnDOTMA, LnDOTMA-(gly $)_{4}$, and LnDOTA-(gly $)_{4}$ complexes as determined by DFT calculations in aqueous solution. Negative free energies indicate that the TSAP isomer is more stable than the SAP isomer. 

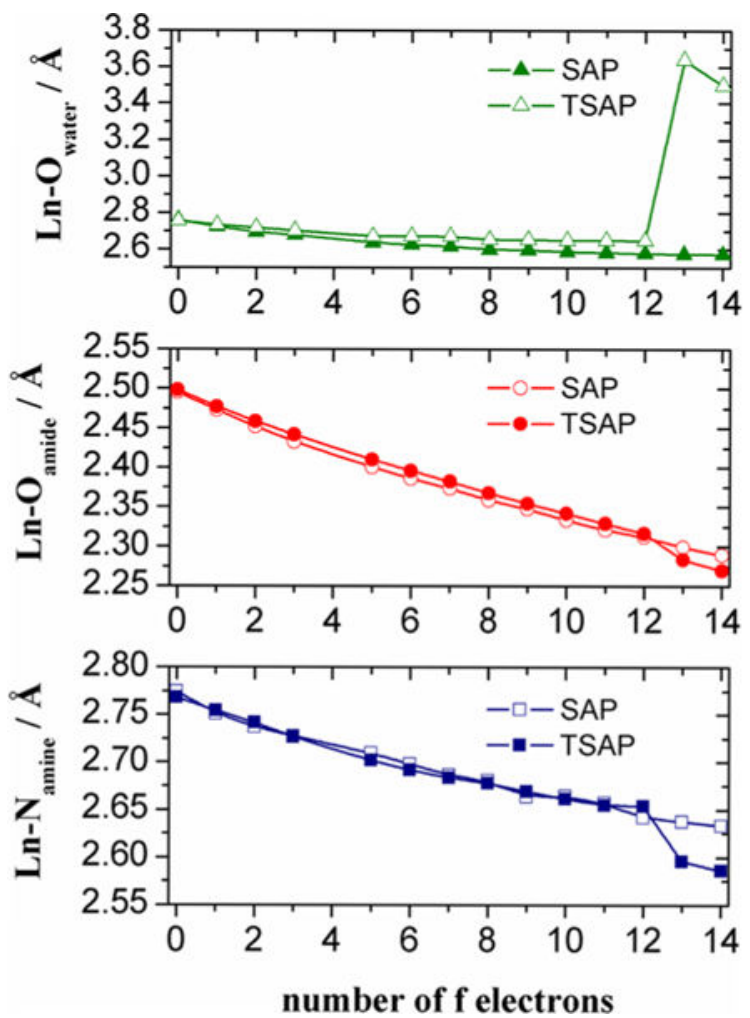

Figure 5.

Ln-Donor distances of LnDOTMA calculated in aqueous solution at the TPSSh/LCRECP/ 6-31(d,p) level. 


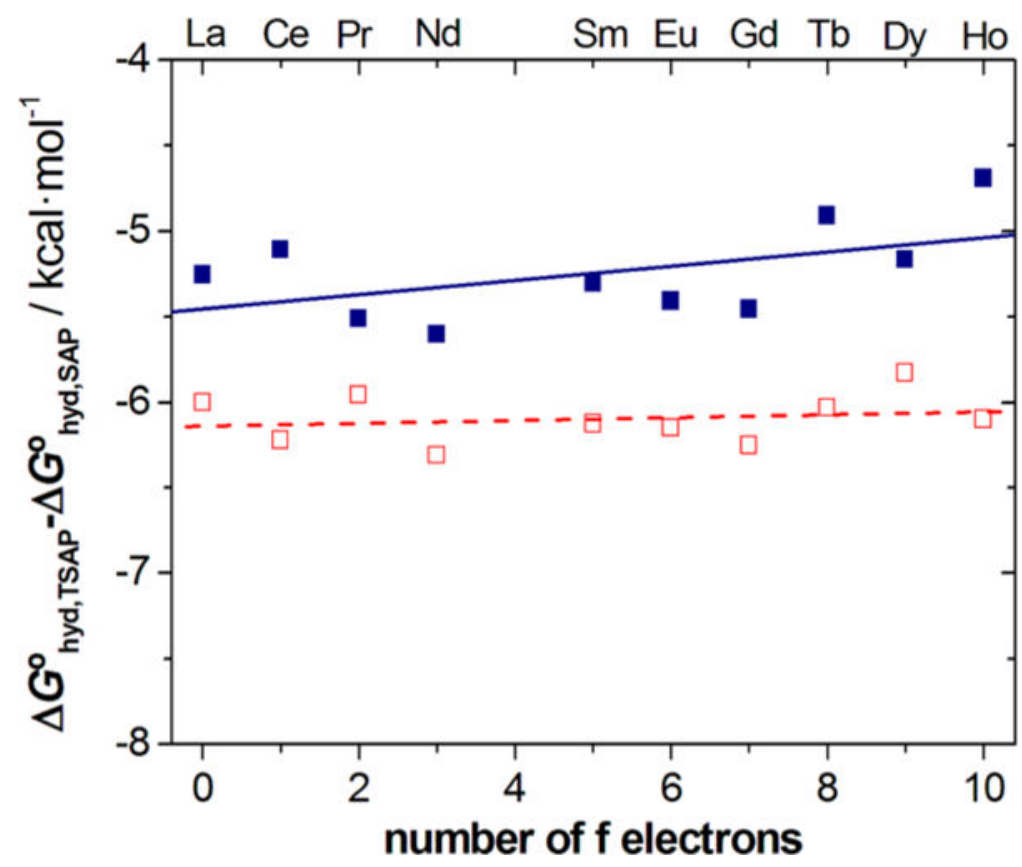

Figure 6.

Difference in hydration free energies between the SAP and TSAP isomers of LnDOTMA and LnDOTMA-(gly $)_{4}$ complexes as determined by DFT calculations in aqueous solution. The solid lines are only intended to guide the eye. 

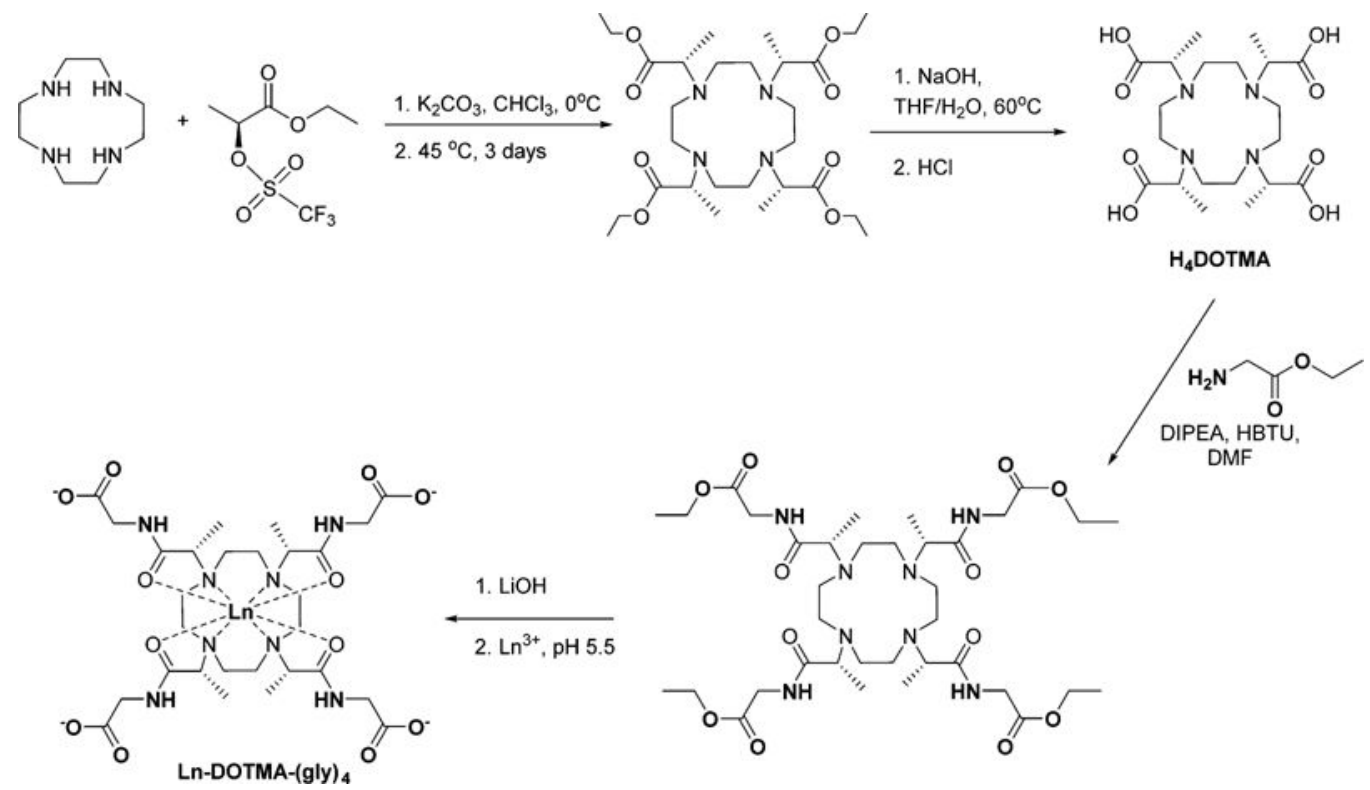

Scheme 1.

Synthesis Scheme for the Ln(III)-DOTMA-(gly ${ }_{4}$ Complexes 

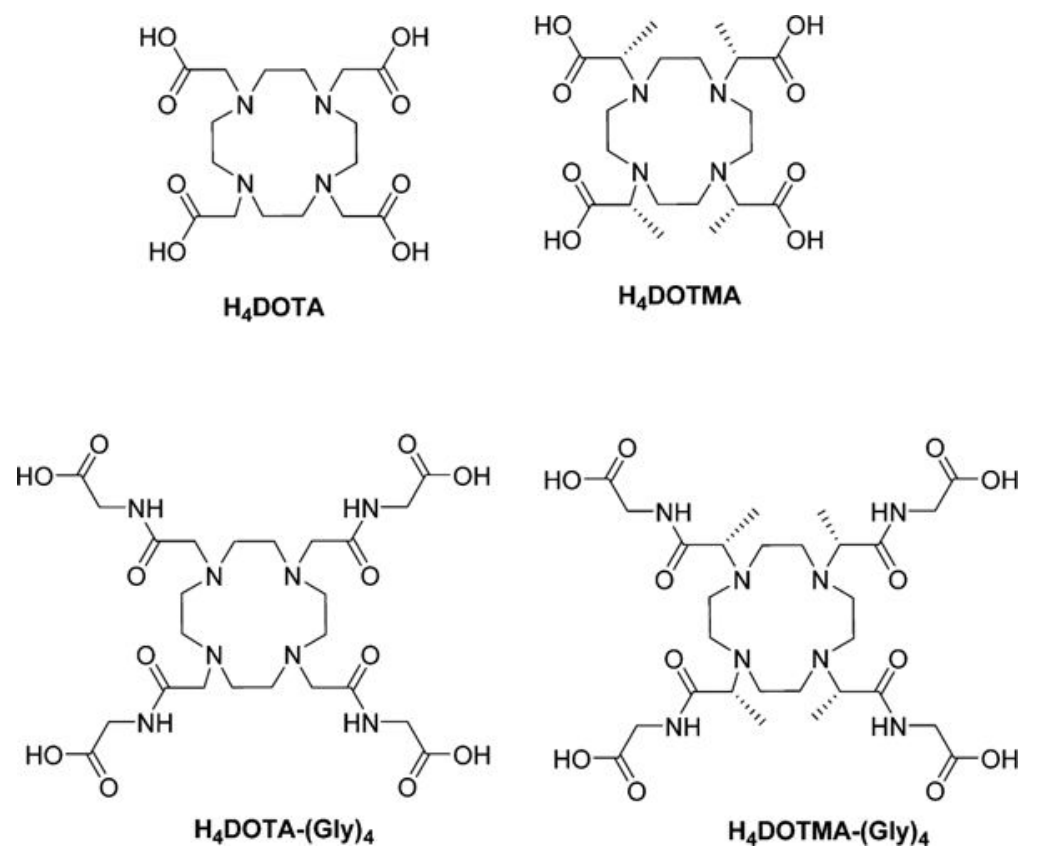

Chart 1.

Chemical Structures of DOTA, DOTMA, DOTA-(gly $)_{4}$ and DOTMA-(gly $)_{4}$ 


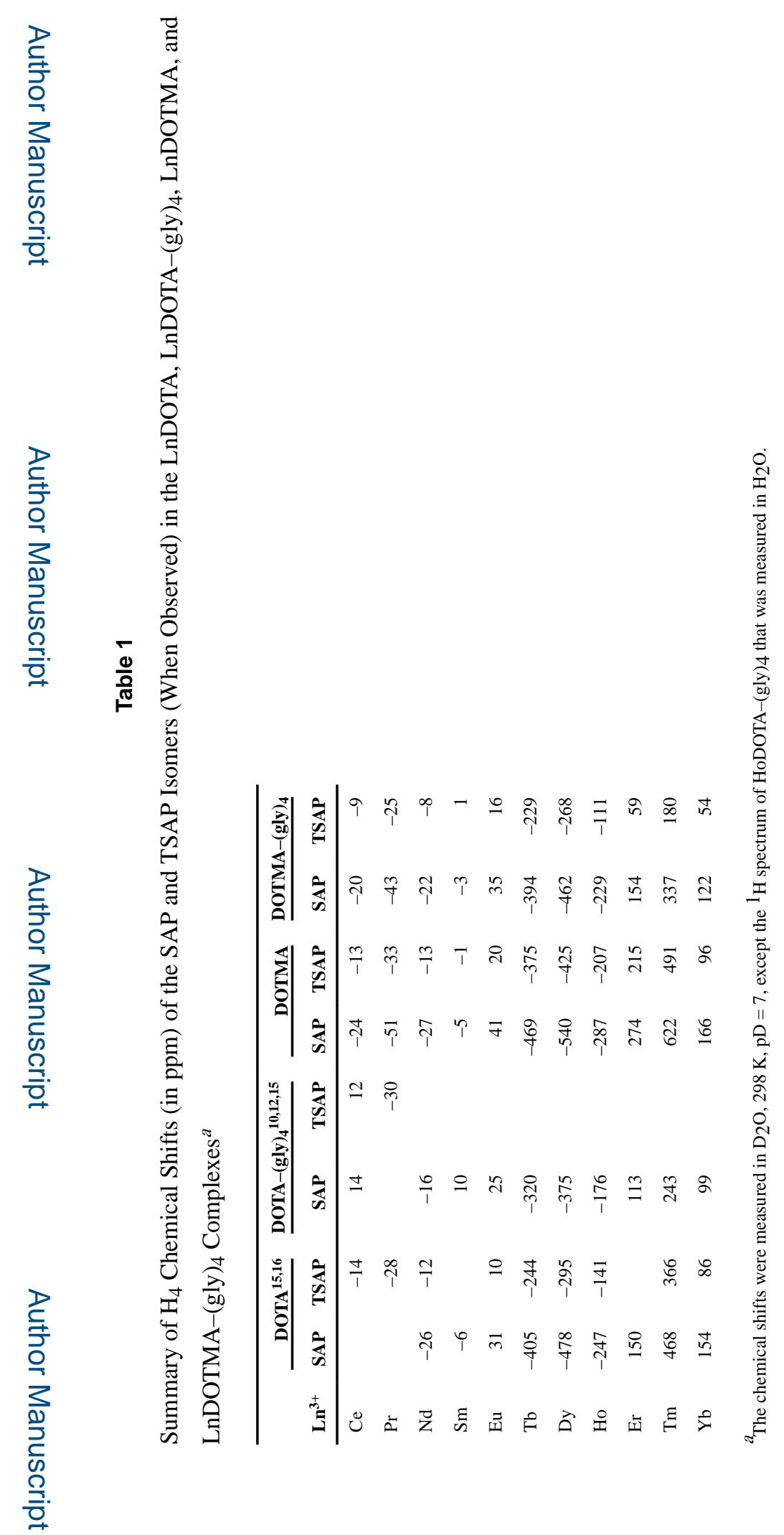

Inorg Chem. Author manuscript; available in PMC 2017 September 19. 


\section{Table 2}

Comparison of the Chemical Shifts $(\delta(\mathrm{ppm}))$ of the $\mathrm{Ln}^{3+}$-Bound Water and Amide Proton Resonances for the Series of LnDOTA-(gly $)_{4}{ }^{12,17}$ and LnDOTMA-(gly $)_{4}$ Complexes (Obtained from CEST Spectra)

\begin{tabular}{lrrrrr}
\hline & \multicolumn{2}{c}{ DOTA-(gly) } & & \multicolumn{2}{c}{ DOTMA-(gly $)_{4}$} \\
\cline { 5 - 6 } $\mathbf{L n}^{3+}$ & $\mathbf{H}_{\mathbf{2}} \mathbf{O}$ & $-\mathbf{N H}$ & & $\mathbf{H}_{\mathbf{2}} \mathbf{O}$ & $-\mathbf{- N H}$ \\
\hline $\mathrm{Pr}$ & -60 & 13 & -85 & 15 \\
$\mathrm{Nd}$ & -32 & 11 & -50 & 10 \\
$\mathrm{Sm}$ & -4 & & -13 & 6 \\
$\mathrm{Eu}$ & 50 & -4 & 66 & -4 \\
$\mathrm{~Tb}$ & -600 & 62 & -752 & \\
$\mathrm{Dy}$ & -720 & 77 & & \\
$\mathrm{Ho}$ & -360 & 39 & & \\
$\mathrm{Er}$ & 200 & -22 & & \\
$\mathrm{Tm}$ & 500 & -51 & & -64 \\
$\mathrm{Yb}$ & 200 & -16 & & -20
\end{tabular}

DOTA-(gly $)_{4} \quad$ DOTMA-(gly $)_{4}$

\begin{tabular}{lrrrr}
$\mathbf{L n}^{3+}$ & $\mathbf{H}_{\mathbf{2}} \mathbf{O}$ & $-\mathbf{N H}$ & $\mathbf{H}_{\mathbf{2}} \mathbf{O}$ & $-\mathbf{N H}$ \\
\hline $\mathrm{Pr}$ & -60 & 13 & -85 & 15
\end{tabular}

$\begin{array}{lllll}\mathrm{Eu} & 50 & -4 & 66 & -4\end{array}$

$-752$ 